\title{
Professional Skepticism: Practitioners' Perceptions And Training Practices
}

\author{
Jodi L. Gissel, Marquette University, USA
}

\begin{abstract}
While regulators criticize auditors for lacking appropriate professional skepticism (SEC, 2010, 2013; PCAOB, 2012), auditing standards lack a clear, consistent definition (Nelson, 2009; Hurtt, Brown-Liburd, Earley, \& Krishnamoorthy, 2013), leaving application of professional skepticism “open to interpretation” (Glover \& Prawitt, 2013, p. 2). If individual auditors view professional skepticism as open to interpretation (i.e., subjective), auditors may believe they are appropriately applying standards on professional skepticism based on their individual interpretations. However, if regulators apply a different definition of professional skepticism when reviewing auditors' work, this may help explain ongoing criticisms from regulators stating auditors lack appropriate professional skepticism. The author reports insights of 66 auditors' perceptions and finds the majority believe professional skepticism has a subjective (as opposed to uniform) definition. This finding is consistent across auditor rank and firm size, suggesting the potential for variations in application of professional skepticism in practice. Supplemental analyses indicate tax practitioners are more likely than auditors to view professional skepticism as subjective, particularly at the partner rank. The author presents professional skepticism training practices for 25 firms that suggest most firms recognize the importance of professional skepticism training and its regular reinforcement. However, there are concerns surrounding the fact that mentoring is listed as the most common training method, which lacks benefits of more formal training activities. Overall, this study provides relevant insights from practitioners and strengthens recent calls for developing a "common definition and shared understanding" of professional skepticism and a framework for evaluating application of professional skepticism (Glover \& Prawitt, 2014, p. 5-6).
\end{abstract}

Keywords: Professional Skepticism; Auditor Skepticism; Tax Practitioner Skepticism; Professional Skepticism Training

\section{INTRODUCTION}

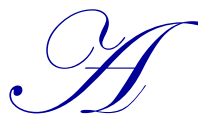

lthough auditing standards emphasize maintaining and applying professional skepticism (PS) throughout audits, regulators criticize auditors for lacking appropriate levels of PS (e.g., SEC, 2000, 2003, 2005, 2010, 2013; PCAOB, 2008, 2012, 2013, 2017). Regulators often link criticisms to another deficiency - such as failure to perform sufficient audit procedures or obtain sufficient evidence (e.g., SEC, 2013; PCAOB, 2016a) or failure to exercise due professional care (e.g, SEC, 2010; PCAOB, 2016b) - and provide little explanation of what specifically constitutes lack of PS; they simply refer to standards that require PS. However, standards (which presumably are the basis for regulators' assessments of auditor performance) lack a clear, consistent definition of PS (Nelson, 2009; Hurtt et al., 2013; Glover \& Prawitt, 2013, 2014) and practical application guidance (Glover \& Prawitt, 2013, 2014).

While acknowledging the need for firm tone at the top and quality control systems to foster an environment of proper PS, the PCAOB (2012, p. 11) specifies "it is ultimately the responsibility of each individual auditor to appropriately apply professional skepticism," highlighting that application of PS is an individual judgment. Based on their individual subjective interpretations, auditors may believe they are appropriately applying auditing standards on PS. However, if regulators employ a different interpretation of PS when reviewing auditors' work, this may contribute to the ongoing criticisms that auditors lack appropriate PS. Therefore, this study explores whether auditors perceive PS as having a uniform (standard) definition or as open to individual subjective interpretation.

Deficiencies in auditors' application of PS may also relate to lack of or ineffective training. While universities strive to develop students' critical thinking skills and introduce issues surrounding PS, this is frequently seen as something that improves with experience over time (Hurtt et al., 2013); in other words, a skill that develops "on-the-job." There is some evidence that training may improve auditors' skeptical judgments and actions (see Nelson, 2009; Hurtt et al., 
2013; Glover \& Prawitt, 2013, 2014), but the form of training influences its effectiveness (Wedemeyer, 2010; Hurtt et al., 2013). Therefore, this study also seeks to develop an understanding of firms' PS training practices in terms of frequency, methods, instructors, and levels of employees who receive training. An understanding of firms' training practices provides insight as to the level of importance firms place on PS and as to whether firms engage in effective training in this area.

This paper reports insights from 66 auditors across ranks (partners, managers, seniors, and staff) and firm sizes (local, regional, national, international, and Big 4) and provides information about training practices at 32 firms. The study finds most individual auditors believe PS is subjective; supplemental analyses indicate this finding is consistent across auditor rank and firm size, suggesting the potential for variation in application of PS in practice. Tax practitioners' views of PS are important to consider as well, as they often participate as specialists during an audit. Supplemental analyses indicate tax practitioners are more likely than auditors to view PS as subjective, particularly at the partner rank, suggesting the need for additional guidance for these specialists. While subjectivity is pervasive in the audit process and individual judgment is necessary, ongoing criticism from regulators suggests we need to reach a common understanding as to the application of appropriate PS. This study provides relevant insights from practitioners that strengthen calls for developing a "common definition and shared understanding" of PS and a framework for evaluating application of PS (Glover \& Prawitt, 2014, p. 5-6), as well as calls for standard setters to consider "whether the standards provide sufficient clarity regarding the requirements with which the auditor should comply and whether the standards are driving auditors to consistent application and to exercise sufficient professional skepticism" (IFIAR, 2017, p. 18).

In addition, this study highlights potential areas for improvement in firm training practices relating to PS. The author finds training practices that suggest most firms recognize the importance of PS training and its regular reinforcement. However, mentoring is the most common training method, which lacks benefits of more formal training activities. This finding should be of interest to academics as well, as it suggests the need for more extensive educational opportunities to develop PS because students may not receive formal training from their firms once they are active in the profession. This need is compounded by recent changes in the Uniform CPA Examination to emphasize advanced critical thinking and analysis skills (Tysiac, 2017), so students cannot wait for "on-the-job" experience to develop this area.

The next section discusses the proposed theoretical model of how individuals' perceptions and training influence interpretations of auditing standards and subsequent skeptical judgments and actions, outlines how relevant auditing standards define PS, and identifies the research questions. The author then presents the study's methodology, followed by a discussion of results and supplemental analyses. The paper concludes with a summary of findings, limitations of the study, and suggestions for application to practice and future research.

\section{THEORETICAL MODEL AND RESEARCH QUESTIONS}

Existing models relating to PS consider a variety of individual auditor characteristics such as traits, experience, and incentives (Nelson, 2009; Hurtt et al., 2013); however, these models do not explicitly incorporate individuals' perceptions of PS. Nelson (2009) illustrates knowledge (including audit experience and training), traits, and incentives as influences on skeptical judgment and action. Hurtt et al. (2013) presents auditor characteristics (including experience and training), evidential characteristics (including auditing standards), client characteristics, and the external environment as antecedents to skeptical judgment and action. Figure 1 presents the proposed theoretical relation of influences on skeptical judgment and action that are the focus of this study, in addition to those considered by Nelson (2009) and Hurtt et al. (2013). Figure 1 illustrates the idea that individuals' perceptions and training influence the interpretation of auditing standards, thereby impacting skeptical judgment and action. 
Figure 1. Additional Influences on Skeptical Judgment and Action

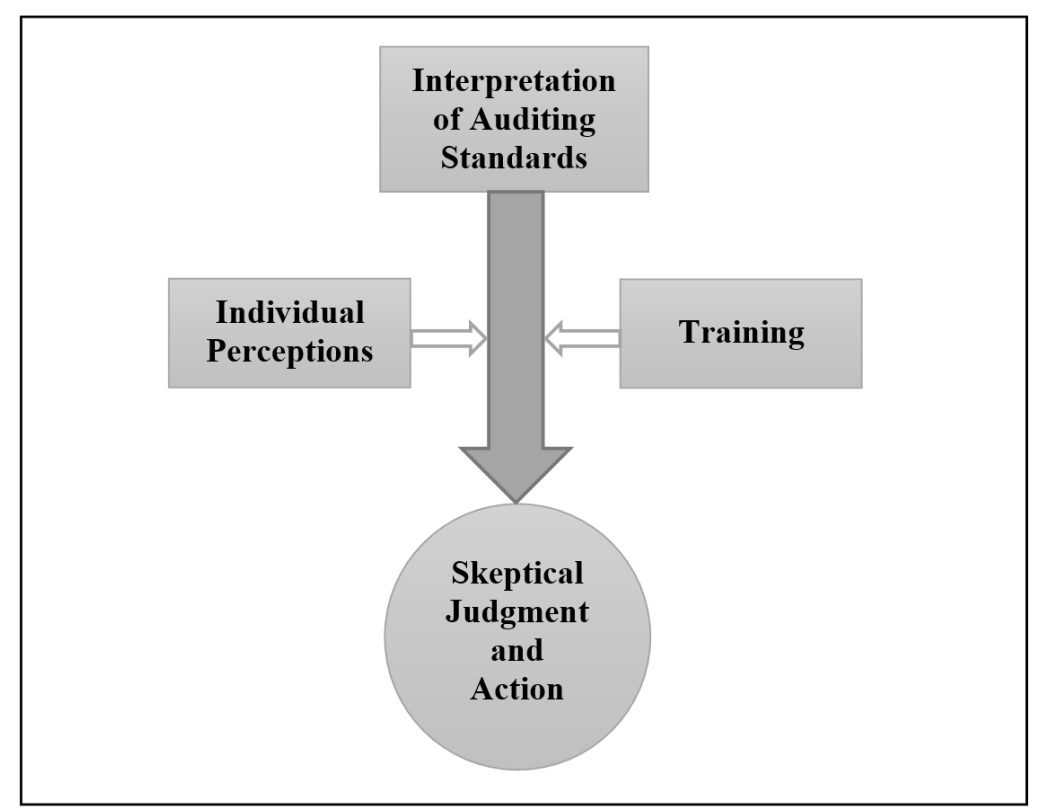

Auditing standards' definitions of PS range from a "neutral" perspective to a "presumptive doubt" perspective (Nelson, 2009; Quadackers, Groot, \& Wright, 2014). For example, PCAOB Auditing Standard (AS) 1015, Due Professional Care in the Performance of Work, presents a neutral perspective, with no presupposition regarding management honesty or dishonesty (Nelson, 2009):

Professional skepticism is an attitude that includes a questioning mind and a critical assessment of audit evidence (paragraph .07); the auditor neither assumes that management is dishonest nor assumes unquestioned honesty (paragraph .09).

On the other hand, PCAOB AS 2401, Consideration of Fraud in a Financial Statement Audit, references PCAOB AS 1015 , but then advocates a presumptive doubt perspective, or an assumption of dishonesty until evidence suggests otherwise (Nelson, 2009):

Professional skepticism is an attitude that includes a questioning mind and a critical assessment of audit evidence. The auditor should conduct the engagement with a mindset that recognizes the possibility that a material misstatement due to fraud could be present, regardless of any past experience with the entity and regardless of the auditor's belief about management's honesty and integrity... [T] he auditor should not be satisfied with less-than-persuasive evidence because of a belief that management is honest. (paragraph .13)

Yet other standards simply indicate auditors should apply PS without any further explanation or guidance. For example, PCAOB AS 2201, An Audit of Internal Control Over Financial Reporting That Is Integrated with An Audit of Financial Statements, states:

The standards, AS 1005, Independence, AS 1010, Training and Proficiency of the Independent Auditor, and AS 1015, Due Professional Care in the Performance of Work, are applicable to an audit of internal control over financial reporting. Those standards require technical training and proficiency as an auditor, independence, and the exercise of due professional care, including professional skepticism. (paragraph .04)

The varying definitions and perspectives of PS in standards "leave open to interpretation what constitutes appropriate levels of questioning of critical assessment” (Glover \& Prawitt, 2013, p. 2). Thus, the basis for regulators' assessments of auditor performance (i.e., auditing standards) does not provide a clear means of measurement. Further, while most standards refer to the neutral definition in PCAOB AS 1015 as a starting point, Nelson $(2009$, p. 3) observes 'regulators 
appear to take more of the "presumptive doubt" perspective, as they typically refer to PS as something that was missing when an audit failure has occurred.'

The PCAOB (2012, p. 14) provides that "when professional skepticism is applied appropriately, the auditor does not presume that the financial statements are presented fairly in conformity with the applicable financial reporting framework. Instead, the auditor employs an attitude that includes a questioning mind in making critical assessments of the evidence obtained to determine whether the financial statements are materially misstated." The PCAOB (2012, p. 11) indicates, "it is ultimately the responsibility of each individual auditor to appropriately apply professional skepticism throughout the audit," emphasizing that PS is an individual judgment. If individual auditors view PS as subject to interpretation (i.e., subjective), auditors may believe they are appropriately applying standards on PS based on their individual interpretations. However, if regulators apply a different interpretation of PS when reviewing auditors' work, this may contribute to ongoing criticisms from regulators stating auditors lack appropriate PS. As such, this study solicits auditors' perceptions of PS to gain insight for the first research question:

\section{RQ1: Do auditors view professional skepticism as having a uniform (standard) definition or as open to} individual subjective interpretation?

Another factor impacting auditors' PS may relate to lack of or ineffective training in the application of PS. While several top academic programs ${ }^{1}$ identify critical thinking or analytical skills as expected learning outcomes (e.g., University of Illinois-Urbana-Champaign ${ }^{2}$, University of Notre Dame ${ }^{3}$, University of Southern California ${ }^{4}$ ), the application of PS is often seen as a skill that develops "on-the-job" or with experience (Hurtt et al., 2013). Training may improve auditors' skeptical judgments and actions (Nelson, 2009; Hurtt et al., 2013; Glover \& Prawitt, 2013, 2014). For example, research suggests positive outcomes of training relating to problem-solving strategies (e.g., Plumlee, Rixom, \& Rosman, 2015) and judgment processes (e.g., Peecher, Solomon, \& Trotman, 2013). However, certain methods may be ineffective at improving PS skills (Wedemeyer, 2010). Therefore, this study also explores firms' PS training in terms of frequency, methods, instructors, and levels of employees who receive training to address the question:

\section{RQ2: What are firms' training practices with respect to professional skepticism?}

\section{METHODOLOGY}

\section{Survey}

The author surveyed practitioners to gain insight regarding perceptions of PS and training practices to address the research questions. The Appendix provides wording of survey items that the author discusses in the results.

With respect to perceptions, respondents indicated whether they believe PS has a standard definition or is more subjective (subject to interpretation at an individual level). The author did not explicitly ask participants to provide their definition of PS because, based on previous discussions with practitioners, responses tend to reference PCAOB AS 1015 paragraph .07 (i.e., questioning mind, critical assessment); however, some add clarification that this is subject to interpretation on a case-by-case basis. These views are present in open-ended responses for this study as well. For example, one respondent states: "A "questioning mind" is critical for assessing information in a public accounting environment.' Another indicates that "once the minimum standards or baseline is met, then there is room for subjective professional skepticism." If individuals believe PS is subjective, an individual's definition may not be consistent from case to case. Therefore, this study focuses not on soliciting definitions, but rather on whether the perception that PS is subjective is widespread and the implications of this worthy of further consideration. Participants were also able to share additional comments or insights in an open-ended item.

\footnotetext{
${ }^{1} \mathrm{http}: / /$ colleges.usnews.rankingsandreviews.com/best-colleges/rankings/business-accounting

${ }^{2}$ https://business.illinois.edu/assuranceoflearning/pdf/bs-mas/Learning-Outcomes.pdf

${ }^{3} \mathrm{https} / / /$ notredame.app.box.com/s/g3376v6fmcmq8s0192wuyiwfpxs152wn

${ }^{4} \mathrm{https}$ :/www.marshall.usc.edu/programs/undergraduate-programs/business-administration/undergraduate-program-learning-objectives
} 
Regarding training, respondents first indicated whether the firm trains employees regarding PS. If yes, respondents identified training frequency, methods, and instructors, as well as the ranks of employees who receive training. ${ }^{5}$ Respondents also indicated what training methods the firm would consider for future training.

\section{Participants}

The author sent 569 "full" surveys (both perception and training) and 201 "brief" surveys (perception only) 6 , for a total of 770 surveys, to members of eight state CPA societies. Full surveys were distributed via email $(\mathrm{N}=456)$ or U.S. mail to participants for whom email addresses were not available $(\mathrm{N}=113)$. Brief surveys were distributed via email $(\mathrm{N}=66)$ or U.S. mail $(\mathrm{N}=135)$. The author received 97 completed responses for the full survey (17 percent response rate) and 73 completed responses for the brief survey ( 36 percent response rate), for a 22 percent overall response rate (170 responses). The overall 22 percent response rate is similar to other accounting studies using survey methodology (e.g., Graham, Hanlon, Shevlin, \& Shroff, 2014, 26.5 percent; Herda \& Lavelle, 2014, 17.1 percent).

For quantitative comparisons relating to the research questions, the author excludes 20 respondents who identify consulting as the primary functional area and 12 with other functions (such as administration or business development), leaving a sample of 138 (67 auditors and 71 tax practitioners). For qualitative discussions, the author includes open-ended comments from all types of respondents.

The auditor sample includes 67 participants across ranks ( 38 partners, 16 managers, nine seniors, and four staff) and firm sizes (31 local, 20 regional, nine national, three international, and four Big 4). The author did not target specific ranks, firm sizes, or client types. ${ }^{7}$ In the text and tables, the author groups similar job titles with partner rank (e.g., owner or director) and manager rank (e.g., senior manager or supervisor). One audit manager from a local firm did not respond to the PS definition item, leaving 66 participants for analyses relating to how auditors perceive the definition of PS. The sample of 71 tax practitioners includes 54 partners, seven managers, eight seniors, and two staff from local (49 respondents), regional (14 respondents), national (three respondents), international (two respondents), and Big 4 (three respondents) firms.

The author limits firm training data to responses from 25 audit partners and seven audit managers, who should be knowledgeable regarding training practices relating to PS. The firm training practices sample represents 32 firms (24 local, five regional, two national, and one Big 4). Participants from international firms and three Big 4 firms did not respond to the full survey with firm training practices items.

\section{RESULTS}

All comparisons use Fisher's exact test, which allows statistical analyses with small samples (Agresti, 1992). Statistical comparisons do not reveal significant differences unless the author notes otherwise in the discussion of results. The paper reports two-tailed $p$-values.

\footnotetext{
${ }^{5}$ The author also asked whether participants believe PS is completely inherent (we are born with it), completely learned (we can be taught it), or both inherent and learned. This was to gain insight as to whether respondents would be receptive, in general, to PS training. Eighty-four percent of auditors respond PS is both inherent and learned, 13 percent that PS is completely learned, and three percent that it is completely inherent. These findings suggest most respondents believe PS is partially or completed learned and, thus, would be receptive to PS training.

${ }^{6}$ The author sent surveys regarding firm training practices to only one practitioner per firm, so response data does not inflate training information.

${ }^{7}$ After the PCAOB (2012) issued Staff Audit Practice Alert No. 10, Maintaining and Applying Professional Skepticism in Audits, the AICPA (2013) reminded members of the Peer Review Program that "while performing a peer review, reviewers should be mindful of challenging the level of professional skepticism that an engagement team exercised on selected audits," emphasizing the importance of PS in all audits (not just those subject to PCAOB oversight).
} 


\section{Perceptions of Professional Skepticism (RQ1)}

Table 1 details auditors' responses as to whether they perceive PS as subjective or uniform.

Table 1. Auditors' Perceptions of Professional Skepticism

\begin{tabular}{|c|c|c|c|c|c|c|c|c|c|c|}
\hline \multirow{3}{*}{$\begin{array}{l}\text { Big } 4 \\
\qquad(\mathrm{~N}=4)\end{array}$} & \multicolumn{2}{|c|}{$\begin{array}{c}\text { Partners } \\
(\mathrm{N}=38)\end{array}$} & \multicolumn{2}{|c|}{$\begin{array}{c}\text { Managers } \\
(\mathbf{N}=15)\end{array}$} & \multicolumn{2}{|c|}{$\begin{array}{c}\text { Seniors } \\
(\mathbf{N}=9)\end{array}$} & \multicolumn{2}{|c|}{$\begin{array}{c}\text { Staff } \\
(\mathrm{N}=4)\end{array}$} & \multicolumn{2}{|c|}{$\begin{array}{c}\text { Total } \\
(\mathrm{N}=66)\end{array}$} \\
\hline & Uniform: & 1 & Uniform: & 1 & Uniform: & 0 & Uniform: & 0 & Uniform: & 2 \\
\hline & Subjective: & 0 & Subjective: & 0 & Subjective: & 1 & Subjective: & 1 & Subjective: & 2 \\
\hline $\begin{array}{c}\text { International } \\
\qquad(\mathrm{N}=3)\end{array}$ & $\begin{array}{l}\text { Uniform: } \\
\text { Subjective: }\end{array}$ & $\begin{array}{l}1 \\
1\end{array}$ & $\begin{array}{l}\text { Uniform: } \\
\text { Subjective: }\end{array}$ & $\begin{array}{l}0 \\
1\end{array}$ & NA & & NA & & $\begin{array}{l}\text { Uniform: } \\
\text { Subjective: }\end{array}$ & $\begin{array}{l}1 \\
2\end{array}$ \\
\hline $\begin{array}{r}\text { National } \\
(N=9)\end{array}$ & $\begin{array}{l}\text { Uniform: } \\
\text { Subjective: }\end{array}$ & $\begin{array}{l}1 \\
4\end{array}$ & $\begin{array}{l}\text { Uniform: } \\
\text { Subjective: }\end{array}$ & $\begin{array}{l}2 \\
1\end{array}$ & $\begin{array}{l}\text { Uniform: } \\
\text { Subjective: }\end{array}$ & $\begin{array}{l}1 \\
0\end{array}$ & NA & & $\begin{array}{l}\text { Uniform: } \\
\text { Subjective: }\end{array}$ & $\begin{array}{l}4 \\
5\end{array}$ \\
\hline $\begin{array}{l}\text { Regional } \\
\qquad(\mathrm{N}=20)\end{array}$ & $\begin{array}{l}\text { Uniform: } \\
\text { Subjective: }\end{array}$ & $\begin{array}{l}3 \\
3\end{array}$ & $\begin{array}{l}\text { Uniform: } \\
\text { Subjective: }\end{array}$ & $\begin{array}{l}2 \\
4\end{array}$ & $\begin{array}{l}\text { Uniform: } \\
\text { Subjective: }\end{array}$ & $\begin{array}{l}0 \\
6\end{array}$ & $\begin{array}{l}\text { Uniform: } \\
\text { Subjective: }\end{array}$ & $\begin{array}{l}0 \\
2\end{array}$ & $\begin{array}{l}\text { Uniform: } \\
\text { Subjective: }\end{array}$ & $\begin{array}{r}5 \\
15\end{array}$ \\
\hline $\begin{array}{l}\text { Local } \\
\qquad(\mathrm{N}=30)\end{array}$ & $\begin{array}{l}\text { Uniform: } \\
\text { Subjective: }\end{array}$ & $\begin{array}{r}6 \\
18\end{array}$ & $\begin{array}{l}\text { Uniform: } \\
\text { Subjective: }\end{array}$ & $\begin{array}{l}0 \\
4\end{array}$ & $\begin{array}{l}\text { Uniform: } \\
\text { Subjective: }\end{array}$ & $\begin{array}{l}1 \\
0\end{array}$ & $\begin{array}{l}\text { Uniform: } \\
\text { Subjective: }\end{array}$ & $\begin{array}{l}1 \\
0\end{array}$ & $\begin{array}{l}\text { Uniform: } \\
\text { Subjective: }\end{array}$ & $\begin{array}{r}8 \\
22\end{array}$ \\
\hline $\begin{array}{l}\text { Total } \\
\quad(\mathrm{N}=66)\end{array}$ & $\begin{array}{l}\text { Uniform: } \\
\text { Subjective: }\end{array}$ & $\begin{array}{l}12 \\
26\end{array}$ & $\begin{array}{l}\text { Uniform: } \\
\text { Subjective: }\end{array}$ & $\begin{array}{r}5 \\
10\end{array}$ & $\begin{array}{l}\text { Uniform: } \\
\text { Subjective: }\end{array}$ & $\begin{array}{l}2 \\
7\end{array}$ & $\begin{array}{l}\text { Uniform: } \\
\text { Subjective: }\end{array}$ & $\begin{array}{l}1 \\
3\end{array}$ & $\begin{array}{l}\text { Uniform: } \\
\text { Subjective: }\end{array}$ & $\begin{array}{l}20 \\
46\end{array}$ \\
\hline
\end{tabular}

Forty-six auditors (70 percent) believe PS is subjective, while 20 auditors (30 percent) view PS as having a uniform definition, indicating a high percentage of auditors believe PS is subject to interpretation at the individual level. Openended comments also reflect this perception. A partner indicates "professional skepticism can mean something very different from one person to another." A manager and another partner provide similar perspectives, stating, respectively: "Professional skepticism has a standard definition, but applying skepticism is highly subjective." and "Once the minimum standards or baseline is met, then there is room for subjective professional skepticism." These comments capture the complexities of PS and its application.

Another partner emphasizes concerns surrounding the difficulties in applying PS, particularly with focusing on extremes: "Some staff can take professional skepticism too far with clients and never trust clients about anything, and some staff never apply professional skepticism and take clients' responses as appropriate all of the time." This comment highlights the tension between trust and PS discussed by Shaub (1996). More recently, Aschauer, Fink, Moro, van Bakel-Auer, and Warming-Rasmussion (2017) explore trust in the auditor-client relationship and find both PS and trust are critical components that can coexist with the appropriate conceptualizations. Overall, comments support the view that "there is a lack of common understanding or practical guidance on what professional skepticism is" (Glover \& Prawitt, 2014, p. 2).

\section{Supplemental Analyses}

\section{$\underline{\text { Auditor Rank }}$}

Extant literature reports mixed findings with respect the relation between experience and PS (Nelson, 2009; Hurtt et al., 2013). While experience can enhance auditors' skepticism and heighten sensitivity to risks, particularly through exposure to frequencies of errors versus non-errors, experience can also lead auditors to discontinue evidence searches if initial findings suggest there are no concerns, thereby overlooking critical information (Nelson, 2009; Hurtt et al., 2013). The possibility exists that, because they have applied PS in a wider variety of circumstances and situations, auditors with more experience could be more likely than those with less experience to believe PS is subjective. Several respondents' comments support this viewpoint:

A partner's view could be very different from a first-year staff.

It has been my experience that you learn when to be skeptical through experience.

Young people do not have the professional experience necessary to know: (1) when to be skeptical and (2) what to be skeptical about. 
Therefore, using auditor rank as a proxy for experience, this study compares auditors' perceptions for partners versus non-partners (managers, seniors, and staff) to consider whether audit partners perceive PS differently than non-partner auditors. Comparing auditors who view PS as subjective in Table 1, partners ( $\mathrm{N}=26$ of 38,68 percent) and non-partners ( $N=20$ of 28,71 percent) are equally likely to have this perception.

\section{$\underline{\text { Audit Firm Size }}$}

Larger firms may be more likely to engage larger, public clients; however, auditing standards apply to private and public, large and small clients alike. Yet, auditors with larger firms may feel more pressure (than those with smaller, local firms) due to PCAOB and SEC scrutiny, making the issue of PS more salient and influencing perceptions. Therefore, the study also compares auditors' perceptions by firm size, considering local firms versus non-local firms (regional, national, international, and Big 4). Twenty-two local firm auditors (of 30, 73 percent) are equally likely as the 24 non-local firm auditors (of 36, 67 percent) to view PS as subjective. Refining the firm size analysis by rank, audit partners from local firms ( $\mathrm{N}=18$ of 24,75 percent) are just as likely as those with non-local firms $(\mathrm{N}=8$ of 14 , 57 percent) to perceive PS as subjective; and non-partner auditors with local firms ( $\mathrm{N}=4$ of 6,67 percent) are just as likely as their counterparts from non-local firms ( $\mathrm{N}=16$ of 22,73 percent) to hold this view. Therefore, there does not appear to be any difference in auditors' perceptions driven by firm size.

\section{$\underline{\text { Tax Practitioners }}$}

Tax practitioners' views of PS are important to consider, as they often participate as specialists during an audit. To the extent tax practitioners' views differ from auditors' perceptions of PS, there could be a mismatch of expectations when conducting audits with tax specialists. In addition, recent studies discuss the importance of PS for tax professionals being alert to potential for tax fraud (DeZoort, Harrison, \& Schnee, 2012; Barker \& Frederick, 2016). Therefore, this study also surveyed tax practitioners to consider whether these practitioners perceive PS differently than auditors. Respondents' comments support this comparison, as one audit partner believes "a tax practitioner will have a different view than an auditor."

Table 2 details tax practitioners' responses. Sixty tax practitioners ( 85 percent) believe PS is subjective, while 11 tax practitioners (15 percent) view PS as having a uniform (standard) definition. Comparisons by rank and firm size do not reveal differences for tax practitioners. Tax partners ( $\mathrm{N}=47$ of 54,87 percent) are just as likely as non-partner tax practitioners ( $\mathrm{N}=13$ of 17,76 percent) to view PS as subjective; and tax practitioners from local firms $(\mathrm{N}=43$ of 49 , 88 percent) are just as likely as those with non-local firms ( $\mathrm{N}=17$ of 22,77 percent) to hold this view. Further refinements by both rank and firm size do not reveal differences either. ${ }^{8}$ Similar to auditors, tax practitioners express concern with the complexities of PS and the tension with trust. One partner states:

This is a difficult concept. We grow up trusting people in general. We believe people are honest, good people. So, it is hard to learn you cannot accept evidence you have gathered at face value. Then, when individuals do learn to question information they are given, they tend to be overly suspicious or cynical. For example, I have a partner who thinks everyone is cheating on their income tax returns. He is an auditor and has considerable training in risk assessment, but I feel he takes it too far.

As noted above, 46 auditors (of 66, 70 percent) view PS as subjective; however, auditors are significantly less likely than tax practitioners ( $\mathrm{N}=60$ of 71,85 percent) to hold this view ( $p=0.043)$. Refinement of this comparison by rank reveals audit partners ( $\mathrm{N}=26$ of 38,68 percent) are significantly less likely than tax partners $(\mathrm{N}=47$ of 54,87 percent) to perceive PS as subjective ( $p=0.038)$. However, non-partner auditors $(\mathrm{N}=20$ of 28,71 percent) and non-partner tax practitioners ( $\mathrm{N}=13$ of 17,76 percent) are equally likely to hold this view. This suggests the overall finding that auditors are less likely than tax practitioners to perceive PS as subjective is driven by the partner rank.

\footnotetext{
${ }^{8}$ Comparisons include tax partners versus non-partner tax practitioners from local firms, tax partners versus non-partner tax practitioners from nonlocal firms, tax partners from local firms versus non-local firms, and non-partner tax practitioners from local firms versus non-local firms.
} 
Table 2. Tax Practitioners' Perceptions of Professional Skepticism

\begin{tabular}{|c|c|c|c|c|c|c|c|c|c|c|}
\hline & \multicolumn{2}{|c|}{$\begin{array}{c}\text { Partners } \\
(\mathrm{N}=54)\end{array}$} & \multicolumn{2}{|c|}{$\begin{array}{c}\text { Managers } \\
(\mathrm{N}=7)\end{array}$} & \multicolumn{2}{|c|}{$\begin{array}{c}\text { Seniors } \\
(N=8)\end{array}$} & \multicolumn{2}{|c|}{$\begin{array}{l}\text { Staff } \\
(\mathrm{N}=2)\end{array}$} & \multicolumn{2}{|c|}{$\begin{array}{c}\text { Total } \\
(\mathrm{N}=71)\end{array}$} \\
\hline $\begin{array}{l}\text { Big } 4 \\
\quad(\mathrm{~N}=3)\end{array}$ & $\begin{array}{l}\text { Uniform: } \\
\text { Subjective: }\end{array}$ & $\begin{array}{l}1 \\
1\end{array}$ & NA & & $\begin{array}{l}\text { Uniform: } \\
\text { Subjective: }\end{array}$ & $\begin{array}{l}0 \\
1\end{array}$ & NA & & $\begin{array}{l}\text { Uniform: } \\
\text { Subjective: }\end{array}$ & $\begin{array}{l}1 \\
2\end{array}$ \\
\hline $\begin{array}{c}\text { International } \\
(\mathrm{N}=2)\end{array}$ & $\begin{array}{l}\text { Uniform: } \\
\text { Subjective: }\end{array}$ & $\begin{array}{l}0 \\
1\end{array}$ & NA & & $\begin{array}{l}\text { Uniform: } \\
\text { Subjective: }\end{array}$ & $\begin{array}{l}1 \\
0\end{array}$ & NA & & $\begin{array}{l}\text { Uniform: } \\
\text { Subjective: }\end{array}$ & $\begin{array}{l}1 \\
1\end{array}$ \\
\hline $\begin{array}{c}\text { National } \\
(\mathrm{N}=3)\end{array}$ & $\begin{array}{l}\text { Uniform: } \\
\text { Subjective: }\end{array}$ & $\begin{array}{l}0 \\
3\end{array}$ & NA & & NA & & NA & & $\begin{array}{l}\text { Uniform: } \\
\text { Subjective: }\end{array}$ & $\begin{array}{l}0 \\
3\end{array}$ \\
\hline $\begin{array}{r}\text { Regional } \\
(\mathrm{N}=14)\end{array}$ & $\begin{array}{l}\text { Uniform: } \\
\text { Subjective: }\end{array}$ & $\begin{array}{l}1 \\
5\end{array}$ & $\begin{array}{l}\text { Uniform: } \\
\text { Subjective: }\end{array}$ & $\begin{array}{l}0 \\
5\end{array}$ & $\begin{array}{l}\text { Uniform: } \\
\text { Subjective: }\end{array}$ & $\begin{array}{l}2 \\
0\end{array}$ & $\begin{array}{l}\text { Uniform: } \\
\text { Subjective: }\end{array}$ & $\begin{array}{l}0 \\
1\end{array}$ & $\begin{array}{l}\text { Uniform: } \\
\text { Subjective: }\end{array}$ & $\begin{array}{r}3 \\
11\end{array}$ \\
\hline $\begin{array}{l}\text { Local } \\
(\mathrm{N}=49)\end{array}$ & $\begin{array}{l}\text { Uniform: } \\
\text { Subjective: }\end{array}$ & $\begin{array}{r}5 \\
37\end{array}$ & $\begin{array}{l}\text { Uniform: } \\
\text { Subjective: }\end{array}$ & $\begin{array}{l}1 \\
1\end{array}$ & $\begin{array}{l}\text { Uniform: } \\
\text { Subjective: }\end{array}$ & $\begin{array}{l}0 \\
4\end{array}$ & $\begin{array}{l}\text { Uniform: } \\
\text { Subjective: }\end{array}$ & $\begin{array}{l}0 \\
1\end{array}$ & $\begin{array}{l}\text { Uniform: } \\
\text { Subjective: }\end{array}$ & $\begin{array}{r}6 \\
43\end{array}$ \\
\hline $\begin{array}{l}\text { Total } \\
\quad(\mathrm{N}=71)\end{array}$ & $\begin{array}{l}\text { Uniform: } \\
\text { Subjective: }\end{array}$ & $\begin{array}{r}7 \\
47 \\
\end{array}$ & $\begin{array}{l}\text { Uniform: } \\
\text { Subjective: }\end{array}$ & $\begin{array}{l}1 \\
6\end{array}$ & $\begin{array}{l}\text { Uniform: } \\
\text { Subjective: }\end{array}$ & $\begin{array}{l}3 \\
5\end{array}$ & $\begin{array}{l}\text { Uniform: } \\
\text { Subjective: }\end{array}$ & $\begin{array}{l}0 \\
2\end{array}$ & $\begin{array}{l}\text { Uniform: } \\
\text { Subjective: }\end{array}$ & $\begin{array}{l}11 \\
60\end{array}$ \\
\hline
\end{tabular}

Refining the comparison of auditors versus tax practitioners by firm size does not reveal differences for local or nonlocal firms. Twenty-two auditors (of 30, 73 percent) and 43 tax practitioners (of 49, 88 percent) from local firms view PS as subjective, while 24 auditors (of 36, 67 percent) and 17 tax practitioners (of 22, 77 percent) from non-local firms hold this view. Further refinements by both rank and firm size do not reveal differences either. Comparisons include local firm partners, non-partners from local firms, partners from non-local firms, and non-partners from non-local firms.

\section{Firms' Professional Skepticism Training Practices (RQ2)}

The firm training practices sample represents 32 firms (24 local, five regional, two national, and one Big 4). Twentyfive of the 32 firms ( 78 percent) train employees regarding PS (20 local firms, three regional firms, one national firm, and one Big 4 firm). Table 3 provides details of training practices for these 25 firms. Participants from international firms did not respond to the full survey with firm training practices items. Also, responses to the full survey were received from only one Big 4 firm. This should not be interpreted to suggest international firms and three Big 4 firms do not provide PS training.

Over half ( $\mathrm{N}=14$ of 25, 56 percent) provide PS training annually and four (16 percent) train on a continuous basis. One firm (4 percent) trains regarding PS only once, upon hire, and the remaining six ( 24 percent) provide training at some other frequency (e.g., as needed or during job evaluations). All 25 firms provide PS training to staff-level employees. Most firms train higher levels as well: 21 (84 percent) train seniors and managers and 17 (68 percent) train partners.

Mentoring by senior professionals is the most common method for PS training ( $\mathrm{N}=22$ of 25,88 percent), followed by lecture or presentation $(\mathrm{N}=14,56$ percent) and conference or off-site continuing professional education $(\mathrm{N}=11,44$ percent). The majority of firms ( $\mathrm{N}=20,80$ percent) use multiple training methods, with four (16 percent) using four or more different PS training methods. However, four firms (16 percent) - all local firms - use mentoring by senior professionals as the sole PS training method. The remaining firm using only one training method indicates training is through engagement team discussions. Firms primarily use internal instructors to provide PS training, most commonly partners $(\mathrm{N}=22,88$ percent).

The training frequency ( $\mathrm{N}=18$ of 25 , or 72 percent, annually or continuously) and training of seniors, managers, and partners suggest firms recognize the importance of PS training and its regular reinforcement. As an audit manager notes: "the quality of professional skepticism is an ongoing process, not an end product." By considering method and instructor data together, responses suggest a common training scenario is mentoring by a partner during engagements. Open-ended survey comments are consistent with this observation:

Professional skepticism is communicated by the partner to the engagement team during every engagement planning meeting.

We are a small firm and as such try to use specific client fact situations to "train" our employees to evaluate whether or not the information or facts we have need to be further tested or confirmed. 
Every engagement is an opportunity to exercise professional skepticism; therefore, staff should receive constant feedback regarding their application of skepticism when completing any task.

As a very small firm...mentoring is our primary method of training outside of formal CPE.

The reason mentoring works best is that it allows the partner to assess whether staff is born with it and can do this well, or needs more experience training. It requires staff having a bit of inquisitiveness in reviewing client data. They must make the right judgement about what to inquire on.

Table 3. Professional Skepticism Training Practices

\begin{tabular}{|c|c|c|c|c|c|}
\hline & \multirow{2}{*}{ Total } & \multicolumn{4}{|c|}{ By Firm Size } \\
\hline & & Local & Regional & National & Big 4 \\
\hline \multicolumn{6}{|l|}{ Training Frequency } \\
\hline Once, upon hire & 1 & 1 & 0 & 0 & 0 \\
\hline Annually & 14 & 12 & 1 & 1 & 0 \\
\hline Continuously ongoing & 4 & 4 & 0 & 0 & 0 \\
\hline \multirow[t]{2}{*}{ Other } & 6 & 3 & 2 & 0 & 1 \\
\hline & 25 & 20 & & & \\
\hline \multicolumn{6}{|l|}{ Level Receiving Training } \\
\hline Partner & 17 & 12 & 3 & 1 & 1 \\
\hline Manager & 21 & 16 & 3 & 1 & 1 \\
\hline Senior & 21 & 16 & 3 & 1 & 1 \\
\hline Staff & 25 & 20 & 3 & 1 & 1 \\
\hline \multicolumn{6}{|l|}{ Training Method } \\
\hline Mentoring by senior professionals & 22 & 18 & 2 & 1 & 1 \\
\hline Lecture or presentation & 14 & 9 & 3 & 1 & 1 \\
\hline Conference or off-site CPE & 11 & 10 & 0 & 1 & 0 \\
\hline Self-study & 7 & 7 & 0 & 0 & 0 \\
\hline Case study & 4 & 3 & 1 & 0 & 0 \\
\hline Role-playing & 3 & 3 & 0 & 0 & 0 \\
\hline Other & 3 & 3 & 0 & 0 & 0 \\
\hline \multicolumn{6}{|l|}{ Number of Different Methods } \\
\hline One & 5 & 5 & 0 & 0 & 0 \\
\hline Two & 8 & 4 & 3 & 0 & 1 \\
\hline Three & 8 & 7 & 0 & 1 & 0 \\
\hline \multirow{2}{*}{ Four or more } & 4 & 4 & 0 & 0 & 0 \\
\hline & 25 & 20 & 3 & 1 & 1 \\
\hline \multicolumn{6}{|l|}{ Training Instructor } \\
\hline \multicolumn{6}{|l|}{ Internal } \\
\hline Partner & 22 & 18 & 2 & 1 & 1 \\
\hline Manager & 7 & 6 & 1 & 0 & 0 \\
\hline Other & 7 & 7 & 0 & 0 & 0 \\
\hline \multicolumn{6}{|l|}{ External } \\
\hline On-site & 4 & 3 & 0 & 0 & 1 \\
\hline Off-site & 11 & 10 & 1 & 0 & 0 \\
\hline
\end{tabular}

Respondents also indicate which training methods they would consider for future training. Table 4 details the number of firms in the training practices sample $(\mathrm{N}=32)$ that would consider each method for future use. Methods that firms would consider for future training follow a similar pattern to current training methods, with mentoring by senior professionals as the most popular choice $(\mathrm{N}=26$ of 32,81 percent) followed by lecture or presentation $(\mathrm{N}=20$ of 32 , 63 percent). 
Table 4. Methods Would Consider for Future Training

\begin{tabular}{l|c}
\hline \multicolumn{1}{c}{ Training Method } & N \\
\hline Mentoring by senior professionals & 26 \\
\hline Lecture or presentation & 20 \\
\hline Conference or off-site CPE & 18 \\
\hline Self-study & 17 \\
\hline Case study & 10 \\
\hline Role-playing & 7 \\
\hline Other & 9 \\
\hline
\end{tabular}

This data also provides insight about satisfaction with training methods. Table 5 details satisfaction level, which the author measures as the percentage of firms that currently use the method and would consider the same method for the future.

Table 5. Satisfaction with Current Training Practices

\begin{tabular}{l|c|c|c}
\hline \multicolumn{1}{c}{ Training Method } & Consider for Future & Currently Used & Satisfaction Level \\
\hline Mentoring by senior professionals & 18 & 22 & $82 \%$ \\
\hline Lecture or presentation & 12 & 14 & $86 \%$ \\
\hline Conference or off-site CPE & 11 & 11 & $100 \%$ \\
\hline Self-study & 7 & 7 & $100 \%$ \\
\hline Case study & 3 & 4 & $75 \%$ \\
\hline Role-playing & 2 & 3 & $67 \%$ \\
\hline Other & 0 & 3 & $0 \%$ \\
\hline
\end{tabular}

This analysis shows 82 percent satisfaction with mentoring by senior professionals and 86 percent satisfaction with a lecture or presentation method. This suggests that while mentoring by senior professionals and lecture or presentation are the most popular choices by respondents for future training activities, firms currently using them may not be as satisfied with these methods as with other methods. There appears to be greater satisfaction with self-study and conference or off-site CPE methods, as 100 percent currently using these methods indicate the firm would also consider using these methods for future training.

\section{CONCLUSIONS}

While the PCAOB (2008, 2012, 2013, 2017) and SEC (2005, 2010, 2013) criticize auditors for not applying appropriate levels of PS, auditing standards lack a clear, consistent definition of PS (Nelson, 2009; Hurtt et al., 2013; Glover \& Prawitt, 2013, 2014) as a basis for regulators' assessments of auditor performance. This study surveys auditors regarding their perceptions to assess whether they view PS as uniform (standard) or as subject to individual interpretation (i.e., subjective). Seventy percent of auditor participants perceive PS as subjective as opposed to having a uniform definition, and this finding is consistent across auditors' ranks and firms. Supplemental analyses indicate auditors are less likely than tax practitioners to perceive PS as subjective, though this difference appears to be driven by the partner rank. One explanation could be auditors have more exposure to discussions and auditing standards addressing PS than tax practitioners. However, this highlights the importance of guidelines for a common understanding of PS for all those involved with the audit process.

The author recognizes conclusions from this study reflect perceptions of those practitioners who responded to the survey. Although the sample is weighted on partners and local firms, there is representation across rank and firm size. A further limitation is potential self-selection bias in the training practices sample. Twenty-five of the 32 firms indicate they provide PS training. While the author does not have reason to believe this is an unreasonable proportion across firms not in the sample, it is possible a greater proportion of auditors from firms training regarding PS responded to the survey. However, the author believes the sample is appropriate and results yield relevant insights regarding perceptions of PS and training practices. These insights are useful to practitioners and regulators in understanding perceptions of PS and considering ways to improve its application. Findings should also be of interest to researchers who investigate PS and to academia as it prepares next-generation practitioners. As one respondent notes: "Higher education has to take a lead role in developing a culture of professional skepticism." The recent changes to the Uniform CPA Examination emphasize the importance of this argument. 
Overall, findings of this study are consistent with the view that the majority of practitioners believe PS is subject to individual interpretation. Allowing practitioners to exercise suitable flexibility when judging unique client situations is important. However, following Nelson's (2009) model of professional skepticism, skeptical actions are based on skeptical judgments, with skeptical judgments a necessary precursor to skeptical actions (Hurtt et al., 2013). As the theoretical model in Figure 1 illustrates, auditors' individual interpretations of PS may lead to variation in skeptical judgments and actions. This has implications for audit planning, as auditors' interpretations of PS may lead them to be overly skeptical and, as a result, "design overly inefficient and expensive audits" (Nelson, 2009, p. 1). Alternatively, auditors' interpretations of PS may lead them to not apply an appropriate level of PS and design ineffective audits. Further, if auditors believe they are appropriately applying standards on PS based on individual interpretations, but regulators apply a different interpretation of PS when reviewing auditors' work, this may help explain ongoing criticisms from regulators stating auditors lack appropriate PS. Another limitation of this study is that most survey questions were closed-type, though participants had the opportunity to provide open-ended comments. However, this study is a first step to explore whether individuals believe PS is subjective before attempting to solicit definitions from individuals. The next step is for future research to consider variations in individuals' definitions of PS and whether an individual's definition changes over time (with experience) and/or in different situations. Similarly, regulators may also apply individual interpretations to define professional skepticism; therefore, future research should explore the regulator perspective.

This study provides relevant insights from practitioners and strengthens recent calls for developing a "common definition and shared understanding" of PS and a framework for evaluating application of PS (Glover \& Prawitt, 2014, p. 5-6), as well as for standard setters to consider "whether the standards provide sufficient clarity regarding the requirements with which the auditor should comply and whether the standards are driving auditors to consistent application and to exercise sufficient professional skepticism" (IFIAR, 2017, p. 18). Participants' comments recognize the difficulties in applying PS, particularly with not taking PS to extremes. A common understanding and framework for evaluating PS would assist practitioners with maintaining an appropriate balance and levels of PS and trust within guidelines. Respondents' comments also suggest views that experience is necessary for skeptical behavior. For example, "Young people do not have the professional experience necessary to know: (1) when to be skeptical and (2) what to be skeptical about." A common understanding and framework for evaluating PS would also respond to these concerns.

Once there is a common understanding and framework for PS, enhanced training within the framework is necessary to improve practitioners' application of PS (Nelson, 2009; Hurtt et al., 2013; Glover \& Prawitt, 2013, 2014). Although firms' training practices suggest they recognize the importance of PS training, the use of mentoring as a primary training method is a concern. While mentoring activities may help auditors develop and enhance PS skills, there is concern because this model "is susceptible to problems when conditions change" (Wedemeyer, 2010, p. 331). Unlike more formal training activities, mentoring likely varies depending on mentors' experiences and circumstances of current engagements used for training purposes. In addition, open-ended responses suggest mentoring mainly emphasizes the importance of PS and provides performance feedback rather than training auditors how to exercise skeptical behavior. This could limit exposure to a variety of scenarios and hinder auditors' abilities to gain a deeper understanding of PS and its application to different situations. Further, with the finding that partners most commonly provide the mentoring, there is concern that an individual partner's views can influence subordinate's PS (Carpenter \& Reimers, 2013; Harding \& Trotman, 2017).

With the widespread view that PS is open to individual subjective interpretation, it is unlikely the profession will achieve more consistent application of PS if training continues to focus on mentoring by partners. Firms should consider more uniform PS training programs to provide opportunities for role-playing and self-assessment to improve auditors' skills applying PS (Peecher et al., 2013; Plumlee et al., 2015). This is an area where the profession, regulators, and academia could work together to develop consistent and effective training to improve application of PS.

\section{ACKNOWLEDGMENTS}

The author thanks the practitioners who participated for sharing their insights, perceptions, and information regarding firm training practices. She also thanks Michael Akers, as well as two anonymous reviewers, for feedback and suggestions to improve this paper. 


\section{AUTHOR BIOGRAPHY}

Jodi Gissel earned her Ph.D. from the University of Wisconsin-Madison in 2010. She is a Certified Public Accountant (Wisconsin) and Certified Fraud Examiner. Her research focuses on factors that influence decision-making, as well as the quality and relevance of related outcomes. She has interests in ethics and fraud-related issues, so her research often intersects these areas. She explores these interests from the diverse perspectives of financial statement preparers, auditors, and users, as well as from an educational standpoint in terms of developing professional knowledge, critical thinking, and decision-making skills.

\section{REFERENCES}

Agresti, A. (1992). A survey of exact inference for contingency tables. Statistical Sciences, 7(1), 131-177.

American Institute of Certified Public Accountants or AICPA (2013). February 2013 Peer Review Update.

Aschauer, E., Fink, M., Moro, A., van Bakel-Auer, K., \& Warming-Rasmussion, B. (2017). Trust and professional skepticism in the relationship between auditors and clients: Overcoming the dichotomy myth. Behavioral Research in Accounting, $29(1), 19-42$.

Barker, J., \& Frederick, C. (2016). Billions lost yearly to Earned Income Tax Credit: Errors or fraud? Journal of Business and Economics Research, 14(4), 145-152.

Carpenter, T. D., \& Reimers, J. L. (2013). Professional skepticism: The effects of a partner's influence and the level of fraud indicators on auditors' fraud judgments and actions. The Accounting Review, 25(2), 45-69.

DeZoort, F. T., Harrison, P., \& Schnee, E. (2012). Tax professionals' responsibility for fraud detection: The effects of engagement type and audit status. Accounting Horizons, 26(2), 289-306.

Glover, S., \& Prawitt, D. (2013). Enhancing auditor professional skepticism. Retrieved from http://www.thecaq.org/enhancingauditor-professional-skepticism.

Glover, S., \& Prawitt, D. (2014). Enhancing auditor professional skepticism: The professional skepticism continuum. Current Issues in Auditing, 8(2), 1-10.

Graham, J. R., Hanlon, M., Shevlin, T., \& Shroff, N. (2014). Incentives for tax planning and tax avoidance: Evidence from the field. The Accounting Review, 89(3), 991-1023.

Harding, N., \& Trotman, K. T. (2017). The effect of partner communications of fraud likelihood and skeptical orientation on auditors' professional skepticism. Auditing: A Journal of Practice \& Theory, 36(2), 111-131.

Herda, D. N., \& Lavelle, J. J. (2014). Auditing subsequent events: Perspectives from the field. Current Issues in Auditing, 8(2), A10-A24.

Hurtt, R. K., Brown-Liburd, H., Earley, C., \& Krishnamoorthy, G. (2013). Research on auditor professional skepticism: Literature synthesis and opportunities for future research. Auditing: A Journal of Practice \& Theory, 32(Supplement 1), 45-97.

International Forum of Independent Audit Regulators or IFIAR (2017). Report on 2016 Survey of Inspection Findings.

Nelson, M. (2009). A model and literature review of professional skepticism in auditing. Auditing: A Journal of Practice \& Theory, 28(2), 1-34.

Peecher, M., Solomon, I., \& Trotman, K. (2013). An accountability framework for financial statement auditors and related research questions. Accounting, Organizations and Society, 38(8), 596-620.

Plumlee, R. D., Rixom, B., \& Rosman, A. (2015). Training auditors to perform analytical procedures using metacognitive skills. The Accounting Review, 90(1), 351-369.

Public Company Accounting Oversight Board or PCAOB. Auditing Standard (AS) 1015, Due Professional Care in the Performance of Work. Retrieved from https://pcaobus.org/Standards/Auditing/Pages/AS1015.aspx

Public Company Accounting Oversight Board or PCAOB. Auditing Standard (AS) 2201, An Audit of Internal Control Over Financial Reporting That Is Integrated with An Audit of Financial Statements. Retrieved from https://pcaobus.org/Standards/Auditing/Pages/AS2201.aspx

Public Company Accounting Oversight Board or PCAOB. Auditing Standard (AS) 2401, Consideration of Fraud in a Financial Statement Audit. Retrieved from https://pcaobus.org/Standards/Auditing/Pages/AS2401.aspx

Public Company Accounting Oversight Board or PCAOB (2008). Report on the PCAOB's 2004, 2005, 2006, and 2007 Inspections of Domestic Annually Inspected Firms. PCAOB Release No. 2008-008. Retrieved from https://pcaobus.org/Inspections/Documents/2008_12-05_Release_2008-008.pdf

Public Company Accounting Oversight Board or PCAOB (2012). Staff Audit Practice Alert No. 10: Maintaining and Applying Professional Skepticism in Audits. Retrieved from https://pcaobus.org/Standards/QandA/12-04-2012_SAPA_10.pdf

Public Company Accounting Oversight Board or PCAOB (2013). Report on 2007-2010 Inspections of Domestic Firms that Audit 100 or Fewer Public Companies. PCAOB Release No. 2013-001. Retrieved from https://pcaobus.org/Inspections/Documents/02252013_Release_2013_001.pdf

Public Company Accounting Oversight Board or PCAOB (2016a). Order Instituting Disciplinary Proceedings, Making Findings, and Imposing Sanctions In the Matter of Jerry L Stanford, CPA and Jerry L Stanford, CPA, Respondents. PCAOB Release No. 105-2016-019. Retrieved from https://pcaobus.org/Enforcement/Decisions/Documents/105-2016-019Stanford.pdf 
Public Company Accounting Oversight Board or PCAOB (2016b). Order Instituting Disciplinary Proceedings, Making Findings, and Imposing Sanctions In the Matter of Chun Cho Kwok, CPA, and KCC \& Associates (a/k/a Chun C. Kwok, a/k/a Kwok, \& Company), Respondents. PCAOB Release No. 105-2016-026. Retrieved from https://pcaobus.org/Enforcement/Decisions/Documents/105-2016-026-KCC-Kwok.pdf

Public Company Accounting Oversight Board or PCAOB (2017). Standing Advisory Group Meeting Panel DiscussionProfessional Skepticism, November 29-30, 2017. Retrieved from https://pcaobus.org/News/Events/Documents/11292017-SAG-meeting/Professional-Skepticism-Briefing-Paper.pdf

Quadackers, L., Groot, T., \& Wright, A. (2014). Auditors' professional skepticism: Neutrality versus presumptive doubt. Contemporary Accounting Research, 31(3), 639-657.

Securities and Exchange Commission or SEC (2000). Accounting and Auditing Enforcement Release No. 1241: In the Matter of Nanette Miller, CPA, Respondent. Retrieved from https://www.sec.gov/litigation/admin/34-42586.htm

Securities and Exchange Commission or SEC (2003). Accounting and Auditing Enforcement Release No. 1787: In the Matter of PricewaterhouseCoopers LLP, Respondent. Retrieved from https://www.sec.gov/litigation/admin/34-47900.htm

Securities and Exchange Commission or SEC (2005). Accounting and Auditing Enforcement Release No. 2237: In the Matter of Deloitte \& Touche LLP, Respondent. Retrieved from https://www.sec.gov/litigation/admin/34-51606.pdf

Securities and Exchange Commission or SEC (2010). Accounting and Auditing Enforcement Release No. 3100: In the Matter of Pollard Kelley Auditing Services, Inc. and Terance Kelley, CPA, Respondents. Retrieved from https://www.sec.gov/litigation/admin/2010/34-61315.pdf

Securities and Exchange Commission or SEC (2013). SEC charges two KMPG auditors for failed audit of Nebraska bank hiding loan losses during financial crisis. Retrieved from http://www.sec.gov/News/PressRelease/Detail/PressRelease/1365171513624

Shaub, M. K. (1996). Trust and suspicion: The effects of situational and dispositional factors on auditors' trust of clients. Behavioral Research in Accounting, 8, 154-174.

Tysiac, K. (2017). Last-minute guide to the updated CPA exam. Journal of Accountancy, 223(4), 40-43.

Wedemeyer, P. (2010). A discussion of auditor judgment as the critical component in audit quality - A practitioner's perspective. International Journal of Disclosure and Governance, 7(4), 320-333. 
APPENDIX 1

Survey Items for Analyses

\section{Perception-Related}

Please indicate whether you believe professional skepticism (choose one)

Has a standard definition

Is more subjective (subject to interpretation at an individual level)

\section{Training-Related}

Does your firm CURRENTLY train employees regarding professional skepticism? (choose one)

Yes (asked to respond to a-d below as well)

No

a. Please indicate the method(s) your firm CURRENTLY uses to train employees regarding professional skepticism (choose all that apply)

Lecture/presentation

Mentoring by senior professionals

Role-playing

Case study

Other (please specify)
Online self-study

Paper-based self-study

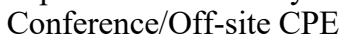

Video (such as YouTube)

b. Please indicate who provides training regarding professional skepticism to your employees (choose all that apply)

Partner (internal)

External presenter on-site

Director (internal)

External presenter off-site (conference, CPE)

Other internal (please specify)

c. Please indicate which level(s) of employees receiving training regarding professional skepticism (choose all that apply)
Staff
Senior
Director
Manager
Partner

d. Please indicate how periodically employees receive training (choose one)

Once (upon hire)

Annually

Once (upon reaching senior level)

Other frequency (please specify)

Please indicate which of the following method(s) your firm would consider FOR FUTURE USE to train professionals with regards to professional skepticism (choose all that apply):

Lecture/presentation

Mentoring by senior professionals

Role-playing

Case study

Other (please specify)

None (firm will not consider training)
Online self-study

Paper-based self-study

Conference/Off-site CPE

Video (such as YouTube) 